\title{
Social Instability, Churches, and Child Witchcraft
}

\author{
Michael Jindra
}

The EPED team of Priest, Ngolo, and Stabell (2020) should be complemented on their project and write-up. This is a tough issue that needs sensitivity to local dynamics, a strong methodology, and the admirable goal of making a difference. The issue brings up core issues of the relationship between Christianity and culture, both of which are dynamic and changing in this situation, complicating the picture even more.

The growth of witchcraft accusations and in particular child-witches, is puzzling but not totally shocking in this context. Instability has riven this part of Africa--political turmoil and violence from the colonial through post-colonial eras, the ravages of HIV/AIDS and more insidiously, the influx of new communicative technologies that brings new entrancing images and narratives, the latter through Nollywood films and internet videos that feature witchcraft as a lead element.

How might this context affect the growth of child witch accusations? One could say that the above instability has created a perfect storm of social order breakdown-both of the state and even more importantly, the family. The EPED research indeed uncovers the connections between family instability and accusations, with accused children often found in step and broken families.

Kinship relations have been the bedrock of order through most of Africa, where the relatively new state structure retains only a loose hold. The reciprocities and hierarchies of family, based on elders, have provided most of the order. The most basic kin rituals, birth, initiation, and especially death, were part of this structure.

The rituals surrounding death are traditionally the biggest life-cycle rituals in Africa, unlike the West, where weddings take precedent. Death rituals, however, have been decimated by the breakdown or overturning of social order. Formerly, and across most of Africa, children were kept from exposure to things associated with death, like funerals. Now, however, children have actually taken over much of death management in Kinshasa. Priest et al. utilize the work of anthropologist Filip de Boeck, who has observed these changes, and who also noted the rise in child witchcraft accusations. $\mathrm{He}$ reports that youth have taken over the "management of death" in Kinshasa, sometimes hijacking funeral processions, making accusations of witchcraft against family members, creating a ludic and sometimes violent atmosphere and demanding money from passersby and family members to acquiesce them (De Boeck 2009).

These are all signs of a breakdown in social order, not entirely surprising in a dynamic, urban place like Kinshasa, at a remove from the land/kinship/political order connection of rural areas. Without kinship, there is a breakdown, a free for all. Where kinship structures are strong, the ancestors are strong, and witches are weaker. The possible replacement, the State, is notably weak and sometimes makes things worse, not better.

This leaves the churches, themselves very diverse, ranging from established churches like the Catholic to independent, sometimes unstable churches. Christianity has had profound effects on notions and practices surrounding personhood, death and misfortune (Jindra and Noret 2011).

In the past, elder men usually controlled society. Men even controlled the afterlife. Personhood, and the status and dignity that came with it, only developed through time, and only by specific acts of fertility or power, like obtaining titles or marrying and having children, who would appeal to you as an ancestor through ritual acts after you die. The dead were also feared because of their association with death pollution and their power to curse after death if neglected by descendants.

Christianity, in contrast, brought dignity and personhood to all classes of people (though at times unevenly and sometimes for cross purposes, as in supporters of apartheid). Christianity grants personhood and the rights that go with it at birth (or before). Where before, in many areas, only certain people were granted an afterlife and the rituals associated with it, Christianity granted burial rites and thus personhood to everyone. Along with other changes, this had a revolutionary effect throughout the continent, giving 
rights to people who never had it before, both socially and politically. Because of this, it was often youth and women who were most strongly attracted to Christianity. Perhaps, given the topic of this article, it went too far, and people began to attribute powers to children that they never had before, including the power to do evil.

Children also provide convenient scapegoats. Unstable times and disorder create a need for scapegoats, and children are the most vulnerable. This theme, stressed most by social theorist Rene Girard, throws us back to basic human social relationships, the inevitable conflicts that occur and how societies through history have dealt with them, often by finding scapegoats. Girard argues that people bond, and even entire cultures form, by acting out against scapegoats, a process found throughout history, most notably by Nazis against Jews in the $20^{\text {th }}$ century, but more also more recently against immigrants, including in places like South Africa. Girard argues that Christ, as a scapegoat, was uniquely innocent, and would not be surprised that the scapegoats here could be said to be the most innocent/vulnerable, children, perhaps Christlike in their own way.

What is the contemporary role of churches in the child witchcraft phenomenon? Churches are some of the strongest institutions throughout Africa, unlike in the West. This gives them power, but like any strong institutions, they are prone to abuse. They evidently played a role in sustaining the accusations, and at times made money off the treatment of child witches. The exploitation of people by church leaders is something found in many places, but certainly here. The role of the EPED team, however, is crucial in limiting and perhaps ending the damage.

As Priest et al. say, it is Christians themselves who are best placed to influence this, like Susan Emmerich a Christian environmentalist who did what secular environmentalists could not-convince religious, conservative Chesapeake Bay fishermen to use sustainable methods of harvesting seafood (Emmerich 2009). Perhaps to combat Nollywood films and lurid YouTube videos, stories and metaphors need to be utilized to create doubts about child witch accusations, as EPED attempts to flip the narrative from children as perpetrators to children as victims.

\section{References}

De Boeck, Filip. 2009. Death Matters; Intimacy, Violence and the Production of Social Knowledge by Urban Youth in the Democratic Republic of Congo. In Can There Be
Life Without Others?. Antonio Pinto Ribeiro, ed. Pp. 44-64. Manchester UK: Carcanet Press Limited.

Emmerich, Susan. 2009. Fostering Environmental Responsibility among Watermen of Chesapeake Bay: A Faith and Action Research Approach. In Mutual Treasure: Seeking Better Ways for Christians and Culture to Converse. Harold Heie and Michael A. King, eds. Pp. 73-92. Telford PA: Cascadia Publishing House.

Jindra, Michael, and Joel Noret. 2011. African Funerals and Sociocultural Change. In Funerals in Africa: Explorations of a Social Phenomenon. Michael Jindra and Joel Noret, eds. Pp. 16-40. New York: Berghahn Books.

Priest, Robert J., Abel Ngolo and Timothy Stabell. 2020. Christian Pastors and Alleged Child Witches in Kinshasa, DRC. On Knowing Humanity Journal 4(1):1-51.

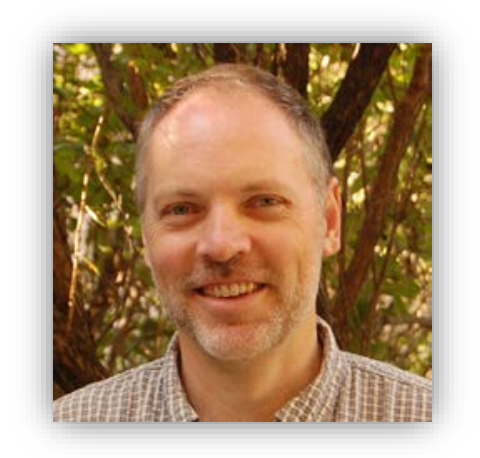

Michael Jindra is a research scholar in the Institute on Culture, Religion and World Affairs at Boston University. His most recent article (co-authored) is "Relational Work in the Struggle Against Poverty: Balancing scholarly critiques and emancipatory practices in the nonprofit sector." Nonprofit \& Voluntary Sector Quarterly, 2020. https://bu.academia.edu/Michael]indra.

Author email: jindraprof@gmail.com 